\title{
The microflora of natural whey cultures utilized as starters in the manufacture of Mozzarella cheese from water-buffalo milk
}

\author{
S. COPPOLA, E. PARENTE, S. DUMONTET, \\ Antonella LA PECCERELLA \\ Istituto di Microbiologia agraria e \\ Stazione di Microbiologia industriale \\ Università degli studi di Napoli - 80055 Portici, Italy
}

\section{Summary}

The composition of 16 natural whey cultures from 3 different Mozzarella cheese plants was investigated. They consisted mainly of lactic acid bacteria, coliform bacteria and yeasts. Micrococci, butyric and propionic acid bacteria only occurred occasionally. Lactobacillus lactis was the most common species of Lactobacillus while Streptococcus lactis and Str. thermophilus were the most common species of Streptococcus. Enteropathogenic Escherichia coli were always present. Different species of Leuconostoc and yeasts belonging to the genera Candida, Kluyveromyces, Debaryomyces and Brettanomyces were also isolated. Acidifying and proteolytic capacity of the strains showed that these activities were widely affected by temperature and type of milk (cow or waterbuffalo milk). Streptococci were the most active acid producers at the cheese vat temperature $\left(37^{\circ} \mathrm{C}\right)$.

Keys words: Water-buffalo Mozzarella cheese - Natural whey cultures.

\section{Résumé}

La microflore naturelle du sérum utilisé comme levain dans la fabrication de la Mozzarelle de bufflonne

On a étudié la composition de 16 cultures naturelles en sérum utilisées comme levain pour la production du fromage «Mozzarella». Ces levains sont formés surtout des bactéries lactiques, des coliformes et des levures.

Les bactéries butyriques, propioniques et les microcoques ont été trouvés épisodiquement et à des niveaux inférieurs.

Les espèces les plus représentées sont Lactobacillus lactis parmi les lactobacilles, Streptococcus lactis et Str. thermophilus parmi les streptocoques, entérocoques inclus.

Parmi les coliformes, Escherichia coli est l'espèce la plus importante du point de vue quantitatif, mais aussi bien pour la présence de sérotypes entéropathogènes. 
Quelques espèces de Leuconostoc et de levures, ces dernières appartenant aux genres Candida, Kluyveromyces, Debaryomyces et Brettanomyces ont été isolées.

Les caractéristiques acidifiantes et protéolytiques des souches isolées sont fort affectées par la température et la nature du milieu utilisé (lait écrémé de vache ou de buflonne).

Les souches de streptocoques étaient les plus actives dans les essais effectués à la température utilisée en fromagerie $\left(37^{\circ} \mathrm{C}\right)$.

Mots clés: Mozzarella de bufflonne - Cultures naturelles en sérum.

\section{Introduction}

Mozzarella cheese made from water-buffalo milk is one of the most highly valued unripened "pasta filata " cheese in Italy.

At present, this type of cheese is still manufactured in the traditional way to ensure its particular organoleptic characteristics: raw whole water-buffalo milk is inoculated with a natural starter, consisting of the whey from the previous manufacture, bringing the acidity of the mixture to $10^{\circ} \mathrm{SH}$ (SoxhletHenkel). The milk is then heated to $36-37^{\circ} \mathrm{C}$ and sufficient rennet is added to obtain coagulation in 20 minutes. After 40 minutes the curd is cut to pieces of about $16 \mathrm{~cm}^{3}$ and left undisturbed, covered by the whey, until curd stretching is possible. This generally occurs 4 hours after the addition of the rennet. During this phase, usually referred to as «curd ripening ", the natural microflora, which comes from both the raw milk and the whey culture, carries out complex biochemical activities, which have been only partially characterized (AdDEo and Coppola, 1983; Coppola et al., 1985). Among these activities, acid development is the most important since only when the $\mathrm{pH}$ is low can enough dicalcium paracasein be converted, during stretching and mixing with hot water $\left(85-900^{\circ} \mathrm{C}\right.$ ), to monocalcium paracasein (CHAPMAN and SHARPe, 1981). Then the curd is milled, stretched and moulded. The whey which is removed from the cheese vat is stored at room temperature $\left(18-22^{\circ} \mathrm{C}\right)$ until used as a starter on the following day.

This manufacturing procedure has at least two consequences : variability in product quality and the risk that pathogenic microorganisms will survive in the finished cheese. In fact, it has previously been shown (ADDEO and Coppola, 1983) that the microbiological quality of water-buffalo milk is extremely variable and usually unsatisfactory ; no particularly selective incubation practice is used on the whey starter during incubation ; acid production and antagonisms by lactic acid bacteria during curd ripening do not ensure the complete disappearence of pathogenic microorganisms; the heat treatment of the curd during stretching is neither even nor completely effective in killing pathogens.

The use of defined starter cultures has been recommended to aid the normal course of acid development and ensure constant quality standards. The Italian Ministry of Health (Ministero della sanita' della Repubblica italiana, 1978), when requiring a heat treatment for milk used in unripened cheese manufacture, pointed out the opportunity of using starter cultures composed of 
Streptococcus thermophilus and a small amount of Lactobacillus bulgaricus or $L b$. helveticus to ensure acid production for curd ripening. According to FormisAno and Mincione (1982) starters composed of Str. thermophilus or Str. lactis and $L b$. bulgaricus are suitable, while VEDAMUTHU and WASHAM (1983) suggest Lb. bulgaricus, Lb. helveticus and Str. thermophilus, and LAW (1982) only Str. thermophilus and Lb. bulgaricus. All the authors cited exclude the participation of other microbial species as a secondary or associated microflora.

Actually, these suggestions have not found any practical application in the manufacture of Mozzarella cheese from water-buffalo milk in Italy. According to the cheese manufacturers, the natural starters cannot be replaced by commercial ones because of the significant loss in the organoleptic qualities of the cheese made with the commercial cultures, compared with the product obtained by the activity of the complex microflora of natural whey cultures.

Therefore a study was carried out to achieve a better knowledge of the microbiological composition of this culture since the rare reports available on natural whey cultures refer to hard cheeses (BotTazzI, 1962; Accolas and Auclair, 1964 ; Matteuzzi, 1967 ; Valles and MocQuot, 1972; BotTazzI and Vescovo, 1973 ; Bottazzi et al., 1977) whose manufacturing technologies are completely different from those of unripened « pasta filata » cheeses.

\section{Materials and methods}

Natural whey cultures used in cheese factories of the Province of Caserta, which is the most typical production area, were examined. A total of 16 samples were taken in January, April, September and December at three cheese factories ( 8 samples in two years from one, 4 samples each in one year from the other two) that utilized exclusively water-buffalo milk for cheese production. The $\mathrm{pH}$ of the samples ranged from 4.17 to 4.23 .

Decimal dilutions of samples were performed in sterile quarter-strength Ringer's solution.

Mesophilic and thermophilic lactic acid bacteria were enumerated in skim milk (Oxoid), using the most probable number (MPN) technique. Test tubes were incubated for $48 \mathrm{~h}$ at $22^{\circ} \mathrm{C}$ and $45{ }^{\circ} \mathrm{C}$ for mesophilic and thermophilic lactic acid bacteria respectively and coagulation of the milk was used as end point. Mesophilic and thermophilic lactobacilli were counted and isolated on Acetate Agar (HARRIGAN and McCANCE, 1976) after anaerobic incubation (BBL Gaspack System) for $48 \mathrm{~h}$ at $22{ }^{\circ} \mathrm{C}$ and $45^{\circ} \mathrm{C}$ respectively. Mesophilic and thermophilic streptococci on Yeast Glucose Lemco Agar (NAYLOR and SHARPE, 1957) after anaerobic incubation (BBL Gaspack system) at $22^{\circ} \mathrm{C}$ and $45^{\circ} \mathrm{C}$ respectively. Since the media used are not selective for lactobacilli or streptococci, enumeration was confirmed by microscopic examination. A plate with about $10^{2}$ colonies was selected for each medium/incubation temperature combination and a number of colonies equal to the square root of the total was picked at random using the Harrison disc described by HARRIGAN and McCANCE (1976). The lactobacilli were maintained as deep cultures respectively in semisolid (0.45\% agar) MRS Agar (DE MAN et al., 1960) and the 
streptococci in semisolid $(0.45 \%$ agar) Yeast-Glucose-Lemco-Agar supplemented with $0.6 \% \mathrm{CaCO}_{3}$; in both media glucose was replaced by lactose.

Enterococci were enumerated in Enterococci Presumptive Broth (Difco), using the MPN technique; positive tubes were confirmed according to the manufacturer's instructions. Strains belonging to this group were also isolated on Yeast-Glucose-Lemco Agar and Barnes Agar (BARNes, 1956), and maintained like the other streptococci.

For the enumeration and isolation of Leuconostoc spp., high-sucrose Mayeux Agar (MAYEuX et al., 1962), incubated at $30^{\circ} \mathrm{C}$ for $48 \mathrm{~h}$, was used. Only large mucoid colonies were counted and isolated. Strains belonging to this genus were also isolated on plates of Yeast-Glucose-Citrate Agar (GARviE, 1967 ) incubated anaerobically at $30^{\circ} \mathrm{C}$ for $48 \mathrm{~h}$. They were maintained on MRS Agar slants.

Because of the lack of suitable selective media, Pediococci were tentatively enriched in Elliker broth (ELLIKER et al., 1956), incubated at $37^{\circ} \mathrm{C}$ for $48 \mathrm{~h}$ and streaked on WL Differential Agar (Difco) plates, which were incubated anaerobically $37^{\circ} \mathrm{C}$ for $48 \mathrm{~h}$, as indicated by Bourgeois and LeveAu (1980).

The most probable number of Micrococcaceae was determined in Tryptic Soy Broth (Difco) with $10 \% \mathrm{NaCl}$, incubated for $48 \mathrm{~h}$ at $37^{\circ} \mathrm{C}$. Aliquots of tubes showing growth were streaked on plates of Mannitol Salt Agar (Difco) and Baird-Parker Agar (Oxoid). Colonies showing the morphology characteristic of Staphylococcus aureus were isolated and maintained on Nutrient Agar (Difco) slants. They were examined for morphology, Gram-reaction, catalase and, after subculturing in Brain Heart Infusion (Difco), for coagulase activity using rabbit plasma (BioMérieux).

Coliform bacteria were enumerated on Violet Red Bile Agar (Oxoid) after $24 \mathrm{~h}$ at $37^{\circ} \mathrm{C}$. McConkey Agar (Difco) and DCLS Agar (BBL) were also used for the isolation of Enterobacteriaceae. The isolates were maintained on Tryptone Glucose Yeast Extract Agar (Difco) slants and identified by means of the API System 20E. A preliminary serological typing was carried out on strains identified as Escherichia coli using Difco and Behering Institute antisera.

Butyric acid bacteria were enumerated using the technique described by ANNIBALDI (1969), incubating the parafin sealed tubes for $5 \mathrm{~d}$. at $30^{\circ} \mathrm{C}$. Propionic acid bacteria were enumerated on the medium of Politi, modified according to GaLli et al. (1984). The plates were incubated anaerobically at $30^{\circ} \mathrm{C}$ for 5 days.

Yeasts were enumerated using Davis' Salt Agar (DAvIS, 1958) adjusted to $\mathrm{pH} 3.5$ with sterile $10 \%$ citric acid solution. Plates were incubated at $26{ }^{\circ} \mathrm{C}$ for 5 days and colonies showing different morphologies were isolated. Yeast isolates were maintained on Malt Agar (Difco), and characterized according to LODDER (1970) and BARNETT et al. (1983).

For each microbial group all the colonies on a plate of $25-50$ were picked for isolation and identification. 
Lactobacillaceae were identified according to Rogosa (1974) while Streptococcaceae were identified according to DIEBEL and SEeley (1974). The techniques utilized are described by HARRIGAN and MCCANCE (1976). The optical isomer of lactic acid was determined according to KRUSH and LOMPE (1982) using Merck reagents and Boehringer enzyme preparations. In addition, the strains were examined for acid production and proteolytic activity in milk. For acid production, strains were subcultured consecutively in skim milk $+0.5 \%$ yeast extract, skim milk $+0.2 \%$ yeast extract and twice in skim milk, incubating each time for $12 \mathrm{~h}$ at $30^{\circ} \mathrm{C}$ for the lactic streptococci and mesophilic lactobacilli, for $12 \mathrm{~h}$ at $45^{\circ} \mathrm{C}$ for the thermophilic lactobacilli and streptococci and for $12 \mathrm{~h}$ at $37{ }^{\circ} \mathrm{C}$ for enterococci. The last subculture was used to inoculate skim milk and skimmed water-buffalo milk, which were incubated at the temperatures indicated above for $4 \mathrm{~h}$ and $6 \mathrm{~h}$ before $\mathrm{pH}$ measurement. A factorial design was used with only two replicates per treatment, because of the very large number of degrees of freedom available to estimate the error mean square. Multiple mean comparisons were carried out using StudentNewman-Keuls' Test. For proteolytic activity the technique of Hull (Hull, 1947) modified by CiтTI et al. (1963) was used. A completely random design with three replicates per strain was used for the statistical evaluation of the data. Multiple mean comparisons were carried out using F-protected Least Significant Difference.

\section{Results}

The ranges of the microbial counts obtained in the different whey starters are summarized in table 1 . No correlation between the time of sampling or between the dairy sampled and the microbial counts for any microbial group was found.

Table 2 reports the results of a statistical analysis carried out on three replicates from a single whey culture sample. Data were log transformed before the confidence limits were estimated.

Over 700 strains were isolated, purified and characterized. Homofermentative isolates from Mayeux agar and isolates from WL-Differential agar not producing DL-lactate were discarded because their biochemical characteristics did not correspond to those of Leuconostoc spp. or Pediococcus spp. respectively. That such strains were isolated on the media is a reflection of the lack of selectively of Mayeux and WL-Differential agars. About $5 \%$ of the strains isolated could not be identified because of various biochemical anomalies. A number of strains were lost before final identification. Finally, 316 strains were identified. Lactobacillaceae, Streptococcaceae and Micrococcaceae are reported in table 3. The last dilution from which a single species was isolated can be regarded as a rough indication of its relative abundance.

Among the lactobacilli, $L b$. lactis was the most frequent species, followed by $L b$. leichmanii and $L b$. salivarius. $L b$. bulgaricus was isolated from a single sample of whey. Its presence suggested the use of a commercial starter culture; however information obtained from the dairy from which this sample was taken suggested that this did not occur. Twelve strains of $L b$. salivarius 


\section{TABLE 1}

Microbial counts in natural whey cultures utilized as starters in Mozzarella cheese manufacture from water-buffalo milk.

$(L O G \text { of } M P N / m l \text { or } C F U / m l)^{a}$

Dénombrements microbiens dans 16 cultures naturelles en sérum utilisées comme levain dans la production du fromage "Mozzarella ».

( $L O G$ du NPP/ml ou $U F C / m l)$

\begin{tabular}{l|c|c}
\hline \multicolumn{1}{c|}{ Microbial group } & Range & Most frequent count \\
\hline Lactic acid bacteria : & & \\
$\quad$ Thermophilic & $7.3-8.3$ & 8.3 \\
$\quad$ Mesophilic & $7.6-7.9$ & 7.9 \\
Thermophilic lactobacilli & $7.0-9.2$ & 8.3 \\
Mesophilic lactobacilli & $6.6-8.0$ & 7.2 \\
Thermophilic streptococci & $7.3-9.3$ & 8.0 \\
Mesophilic streptococci & $7.3-8.7$ & 8.3 \\
Enterococci & $6.9-8.0$ & 7.5 \\
Leuconostocs & $4.6-6.7$ & 5.2 \\
Micrococci & $0.6-3.2$ & 0.6 \\
Coliform bacteria & $4.6-6.0$ & 0.9 \\
Propionic acid bacteria & $0-3.0$ & 0.2 \\
Butyric acid bacteria & $0.8-0.01$ & 5.9 \\
Yeasts & $4.1-7.4$ & \\
\hline
\end{tabular}

a The number of the cultures examined was 16 .

TABLE 2

Statistical analysis of 3 replicates from a single natural whey culture utilized as starter in Mozzarella cheese manufacture from water-buffalo milk

Analyse statistique des 3 répétitions d'un dénombrement microbien dans 1 culture naturelle en sérum utilisée comme levain dans la production du fromage "Mozzarella " ( $L O G$ du NPP/ml ou UFC/ml)

\begin{tabular}{l|c|c}
\hline \multicolumn{1}{c|}{ Microbial group } & Mean ${ }^{\mathrm{a}}$ & Conf. limits $(\mathrm{p}=5 \%)^{\mathrm{a}}$ \\
\hline Lactic acid bacteria : & & \\
$\quad$ Thermophilic & 8.0 & $6.5-9.5$ \\
$\quad$ Mesophilic & 7.6 & $6.9-8.4$ \\
Thermophilic lactobacilli & 7.0 & $6.9-7.1$ \\
Mesophilic lactobacilli & 6.6 & $6.6-6.7$ \\
Thermophilic streptococci & 7.5 & $7.4-7.5$ \\
Mesophilic streptococci & 8.0 & $7.1-8.9$ \\
Enterococci & 7.5 & $6.4-7.0$ \\
Leuconostocs & 6.7 & $6.4-7.0$ \\
Micrococci & 0.7 & $0.3-1.0$ \\
Coliform bacteria & 6.0 & $5.9-6.2$ \\
Propionic acid bacteria & none & $0.6-0.2$ \\
Butyric acid bacteria & -0.2 & $5.2-5.4$ \\
Yeasts & 5.3 & \\
\hline
\end{tabular}

${ }^{\text {a }} \mathrm{LOG} \mathrm{MPN} / \mathrm{ml}$ or $\mathrm{CFU} / \mathrm{ml}$. 
TABLE 3

Lactobacillaceae, Streptococcaceae and Micrococcaceae isolated from natural whey cultures utilized for Mozzarella cheese manufacture from water-buffalo milk

Lactobacillaceae, Streptococcaceae et Micrococcaceae isolées de cultures naturelles en sérum utilisées comme levain dans la production du fromage « Mozzarella»

\begin{tabular}{l|c|c}
\hline \multicolumn{1}{c|}{ Species } & $\begin{array}{c}\text { Last positive } \\
\text { sample dilution }\end{array}$ & $\begin{array}{c}\text { Number } \\
\text { of strains }\end{array}$ \\
\hline Lb. lactis & $10^{-7}$ & 25 \\
Lb. leichmanii & $10^{-7}$ & 10 \\
Lb. salivarius & $10^{-6}$ & 13 \\
Lb. helveticus & $10^{-7}$ & 4 \\
Lb. bulgaricus & $10^{-7}$ & 1 \\
Lb. fermentum & $10^{0}$ & 3 \\
Lb. viridescens & $10^{-5}$ & 1 \\
Lb. casei & $10^{-5}$ & 1 \\
Lb. casei subsp. pseudoplantarum & $10^{-7}$ & 1 \\
Lb. plantarum & $10^{-7}$ & 7 \\
Str. lactis subsp. lactis & $10^{-8}$ & 81 \\
Str. lactis subsp. cremoris & $10^{-7}$ & 2 \\
Str. lactis subsp. diacetylactis & $10^{-7}$ & 8 \\
Str. faecium & $10^{-6}$ & 2 \\
Str. faecalis & $10^{-3}$ & 3 \\
Str. salivarius subsp. thermophilus & $10^{-8}$ & 14 \\
Leuc. dextranicum & $10^{-5}$ & 7 \\
Leuc. lactis & $10^{-4}$ & 1 \\
Leuc. cremoris & $10^{-5}$ & 1 \\
Staph. aureus & $10^{-3}$ & 7 \\
\hline
\end{tabular}

did not produce acid from sorbitol. A strain which did not ferment trehalose was identified as $L b$. lactis and one which did not ferment amygdalin as $L b$. leichmanii. These biochemical anomalies were less frequent among the streptobacteria: a strain that did not produce acid from melizitose was identified as $L b$. casei and six strains were tentatively identified as $L b$. plantarum. Thermophilic lactobacilli were identified more frequently than mesophilic ones.

Identification of streptococcal strains showed, without doubt, that Streptococcus lactis subsp. lactis and Str. salivarius subsp. thermophilus were the most common species; yet, strains belonging to Str. lactis subsp. diacetylactis and Str. lactis subsp. cremoris were isolated from the higher dilutions of the whey cultures examined. Non-hemolytic streptococci, identified as Str. faecium and Str. faecalis were isolated from lower dilutions. However, enterococci were found in all the samples studied.

Leuc. dextranicum was the species of Leuconostoc most easily isolated, probably because of the "selectivity " of the high sucrose medium used. Leuc. cremoris and Leuc. lactis were occasionally isolated. 


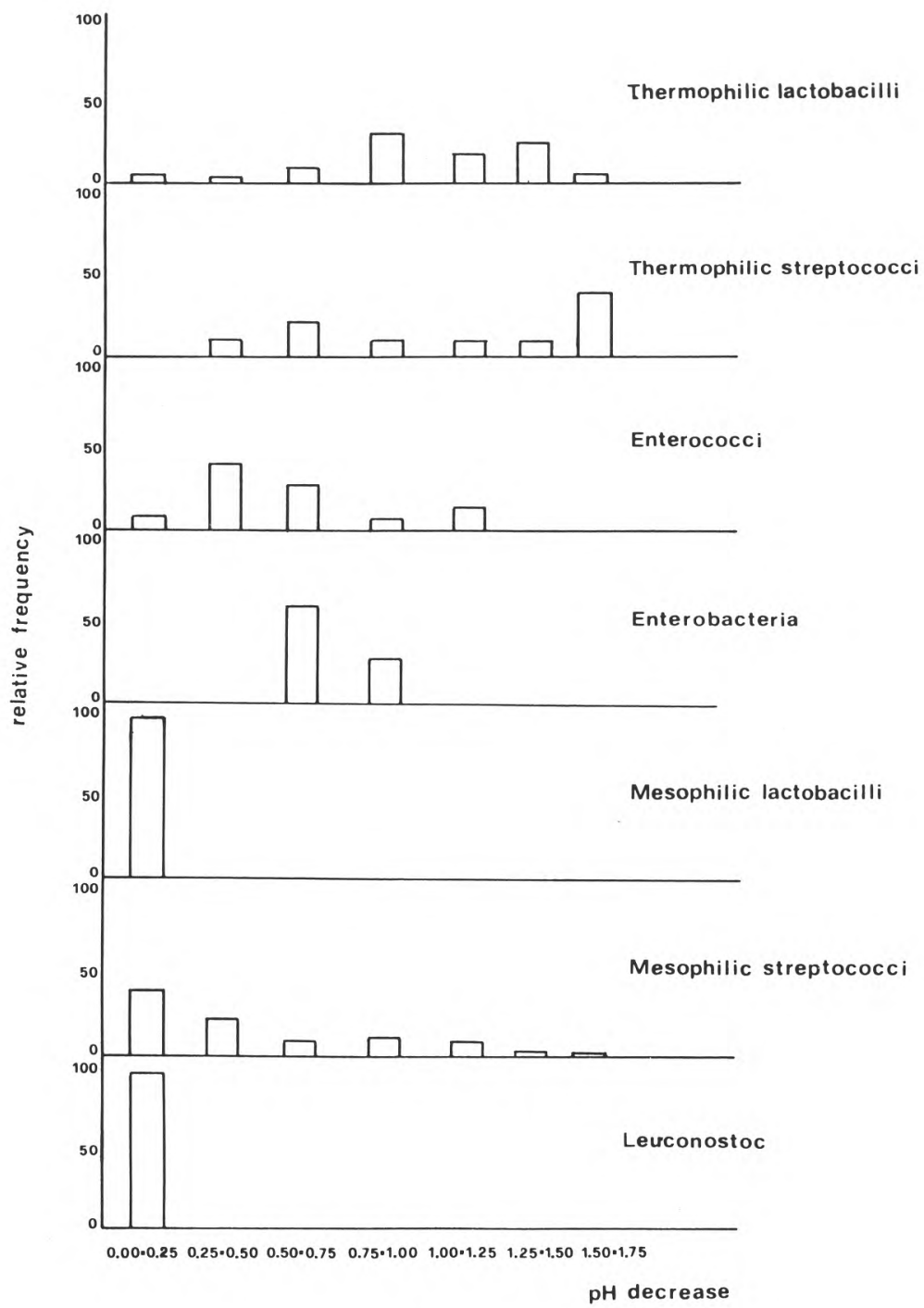

Fig. 1

Acid-producing ability in bovine skim milk (see the text for temperature of incubation) of the strains isolated from natural whey cultures utilized as starters in the manufacture of water-buffalo Mozzarella cheese.

Production d'acide dans le lait écrémé de vache par des souches isolées de cultures naturelles en sérum utilisées comme levains dans la production du fromage "Mozzarella». 
All isolates from Mannitol Salt and Baird-Parker media were coagulase positive and were presumptively identified as Staphylococcus aureus.

The majority of the strains belonging to the family Enterobacteriaceae was identified as Escherichia coli. A preliminary screening with antisera against enteropathogenic and enterotoxigenic strains of this species showed that 4 were agglutinated by Difco $E$. coli $\mathrm{OK}$ antiserum Poly-A $\left(10^{-4}\right), 7$ by Poly-B $\left(10^{-4}\right)$, 3 by Poly-C $\left(10^{-5}\right), 17$ by Poly-D $\left(10^{-5}\right), 2$ by Poly-E $\left(10^{-4}\right), 2$ by both Poly-A and $-\mathrm{B}\left(10^{-4}\right), 1$ by both Poly-B and $-\mathrm{C}\left(10^{-4}\right), 1$ by Poly-A, $-\mathrm{B}$ and $-\mathrm{C}\left(10^{-4}\right)$, 1 by both Poly-C and -D $\left(10^{-4}\right), 4$ by both Poly-D and -E $\left(10^{-4}\right)$ and 50 were not agglutinated. 4 strains were identified as Enterobacter agglomerans $\left(10^{-5}\right)$ and 10 strains as Klebsiella pneumoniae $\left(10^{-6}\right)$. The figure in brackets is the dilution of whey starter from which such strains were isolated. 18 strains showed atypical biochemical profiles and were not identifiable with API System 20E.

In general identification of yeast strains was limited to the genus. 1 strain was identified as Debaryomyces hanseni (highest dilution from which this species was isolated : $10^{-6}$ ), it fermented glucose and galactose ; 2 strains were identified as Kluyveromyces marxianus $\left(10^{-6}\right)$, fermenting glucose, galactose and lactose ; 3 strains were identified as Brettanomyces $\left(10^{-6}\right)$ two of which fermented glucose, galactose and lactose ; 30 strains were identified as Candida $\left(10^{-6}\right): 27$ of them fermented glucose and galactose, 3 strains did not.

Figure 1 shows the acid-producing ability in bovine skim milk of the different groups isolated. Thermobacteria and mesophilic and thermophilic streptococci produced the greatest amounts of acid.

All the Leuconostoc strains and the mesophilic lactobacilli showed very low acid-producing ability and the enterobacteria showed an intermediate one. Differences among strains of all groups were highly significant, as demonstrated by analysis of variance (data not shown).

Figure 2 summarizes some central tendency and dispersion statistics of the distribution of acid-producing ability of the groups mentioned above. Horizontal and vertical bars show the range of acid-producing ability in skimmed bovine milk and water-buffalo milk respectively and intersect at medians. 25th and 75 th precentiles are shown as tics on the bars.

Analysis of variance (data not shown) showed that for the mesophilic lactobacilli, acid production in bovine skim milk was significantly higher $(\mathrm{p}=1 \%)$ than that in water-buffalo skimmed milk, without interaction between the sources of variability (bacterial strain and milk type). On the contrary, for the thermophilic lactobacilli and the Leuconostoc spp. interaction is highly significant. The majority of the strains of these groups had higher acid production in bovine skim milk, but some strains showed the reverse pattern. In contrast, the enterococci and thermophilic streptococci had higher acid-producing ability in water-buffalo skimmed milk; the interaction between strain of bacteria and species of milk was highly significant. Mesophilic streptococci did not show differences between species of milk nor bacterial strain-species of milk interaction. Enterobacteria produced almost twice as much acid in bovine skim milk as in water-buffalo skimmed milk (the diffe- 


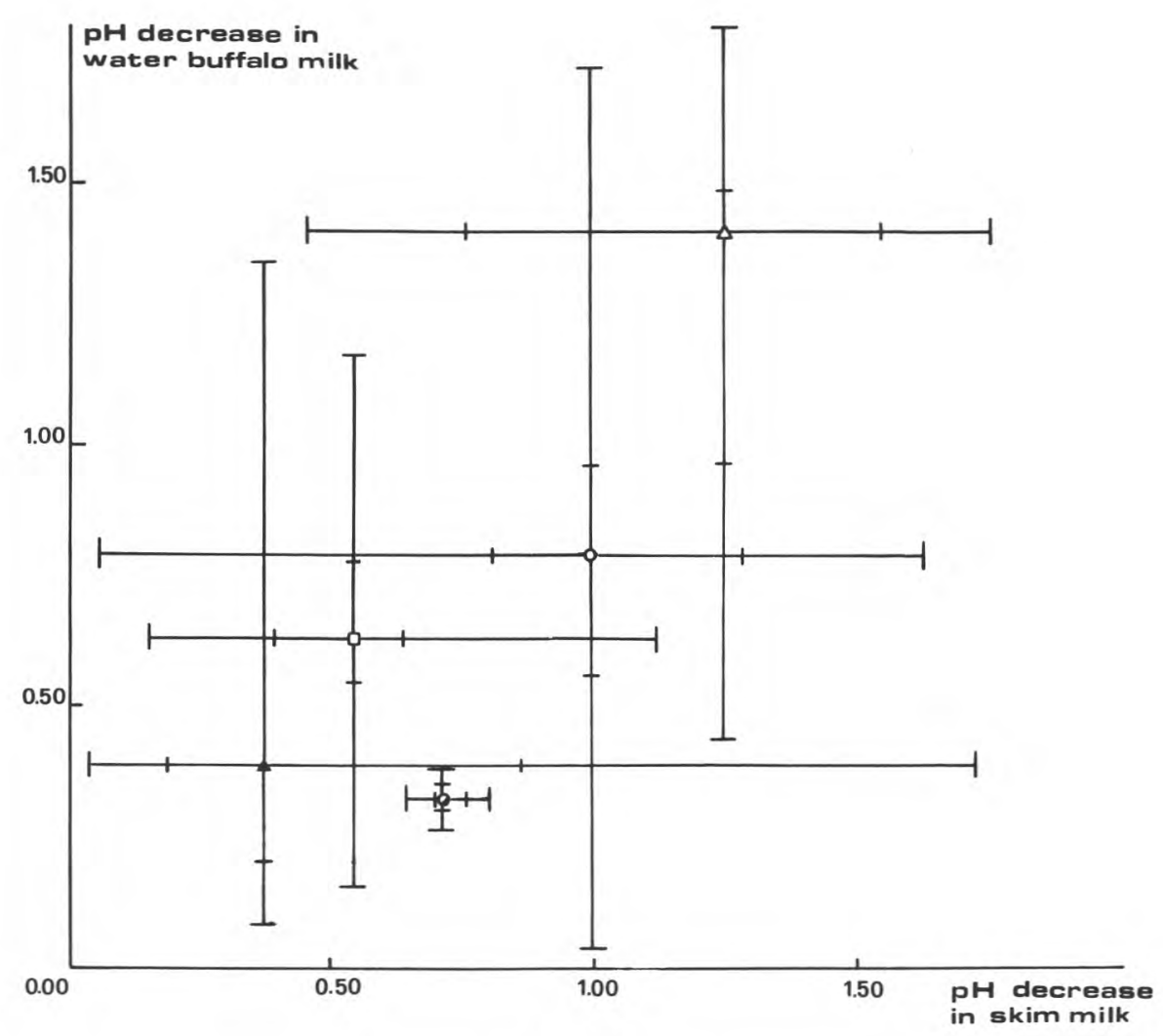

Fig. 2

Central tendency and dispersion statistics on the distribution of acid-producing ability in the taxonomical groups of strains isolated from natural whey cultures utilized as starters in the manufacture of water-buffalo Mozzarella cheese. Horizontal and vertical bars show the range of acid producing ability after $6 \mathrm{~h}$ in skim milk and skimmed water buffalo milk respectively and intersect at medians. 25th and 75th percentiles are shown as tics on the bars.

Tendance centrale et statistiques de dispersion pour la distribution de la capacité acidifiante dans les groupes taxonomiques des souches isolées de cultures naturelles en sérum utilisées comme levain dans la production du fromage "Mozzarella". Les lignes horizontales et verticales définissent la fourchette de production d'acide après $6 \mathrm{~h}$ dans le lait écrémé de vache et le lait écrémé de bufflonne respectivement. Les lignes s'entrecoupent en correspondance de la médiane. Le $25^{e}$ et le $75^{e}$ percentiles sont individualisés par des traits sur les lignes.

thermophilic lactobacilli

- mesophilic streptococci

$\triangle$ thermophilic streptococci

- enterobacteria

$\square$ enterococci 
rence was significant at the $1 \%$ level) ; interaction was not statistically significant.

Figure 3 shows the distribution of thermobacteria, mesophilic and thermophilic streptococci and enterococci on the basis of $\mathrm{pH}$ decreases in bovine skim milk after 6 hours of incubation at cheese vat temperature $\left(36-37^{\circ} \mathrm{C}\right)$. At this temperature the majority of thermophilic lactobacilli showed a lower acidproducing ability, and only caused the $\mathrm{pH}$ of skim milk to decrease of 0.5 1 units. The most active acid-producers were the thermophilic streptococci.

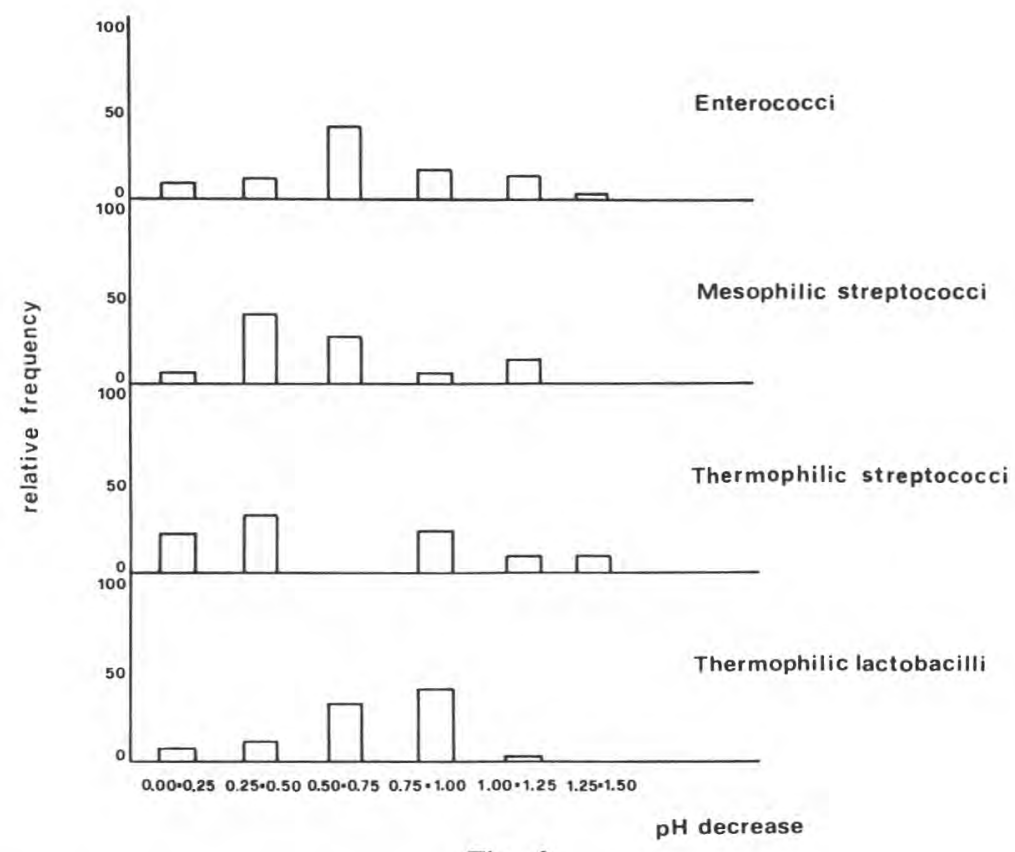

Fig. 3

Acid-producing ability in bovine skim milk at $37^{\circ} \mathrm{C}$ of the strains isolated from natural whey cultures utilized as starters in the manufacture of water-buffalo Mozzarella cheese. Production d'acide dans le lait écrémé de vache à $37{ }^{\circ} \mathrm{C}$ par des souches isolées de cultures naturelles en sérum utilisées comme levain dans la production du fromage "Mozzarella ».

Moreover, a fair number of enterococcal strains (about $13 \%$ ) were able to reduce the $\mathrm{pH}$ of skim milk by $1-1.25$ units at this temperature. The mesophilic streptococci (mainly Str. lactis) showed a surprisingly high acid-producing ability at this temperature. Under the same experimental conditions, natural whey cultures caused a $\mathrm{pH}$ decrease of $0.85-0.88$ units in skim milk and 0.901.13 units in water-buffalo skimmed milk. Figure 4 shows the distribution of the groups on the basis of their proteolytic activities in bovine skim milk. Enterococci had the highest proteolytic activity; some were able to release 


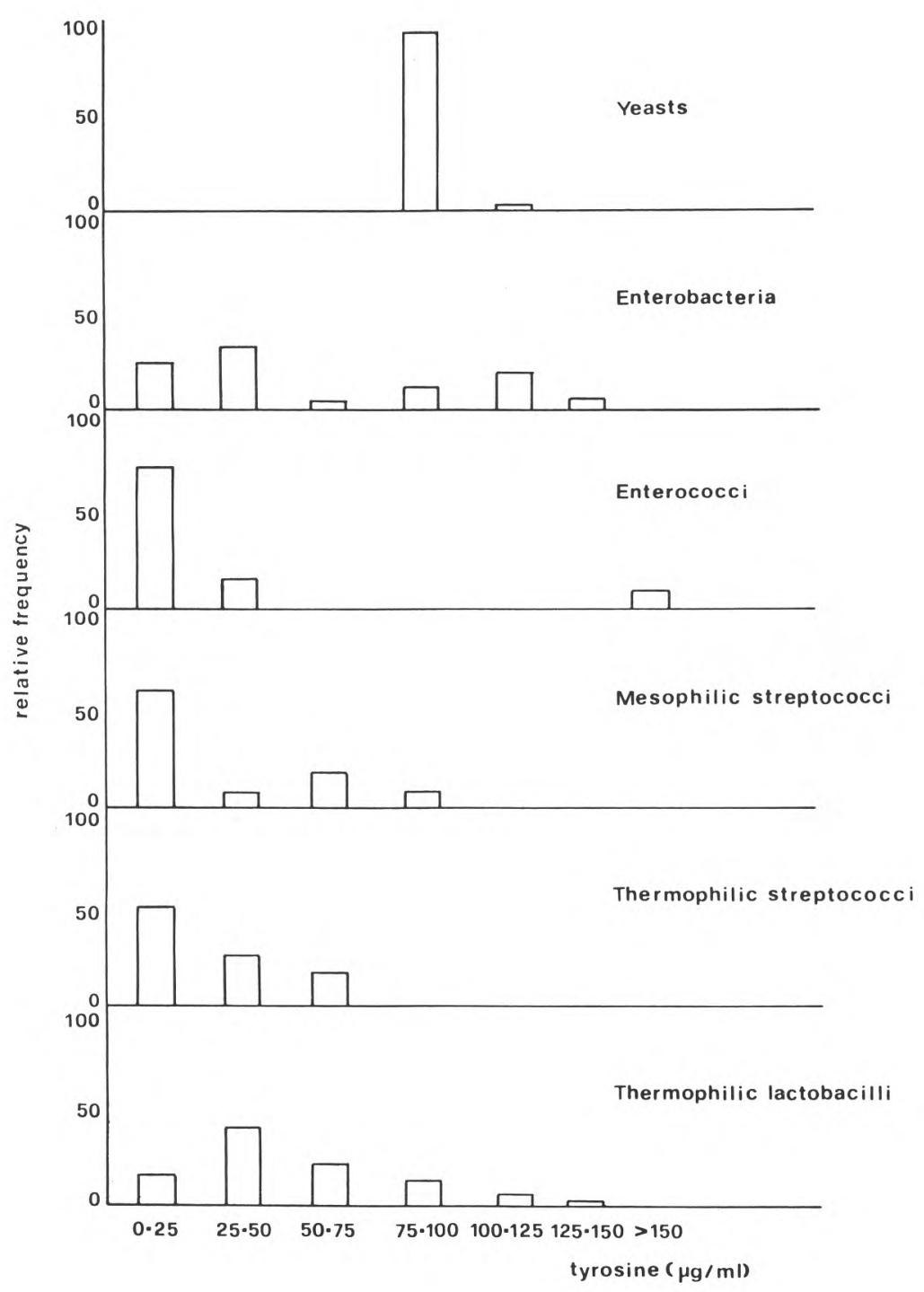

Fig. 4

Proteolytic activity in bovine skim milk (see the text for temperature of incubation) of the strains isolated from natural whey cultures utilized as starters in the manufacture of water-buffalo Mozzarella cheese.

Activité protéolytique à $37^{\circ} \mathrm{C}$ dans le lait écrémé de vache de souches isolées de cultures naturelles en sérum utilisées comme levain dans la production du fromage "Mozzarella». 
more than $150 \mu \mathrm{g}$ tyrosine/ml. Typically, the strains of this group could be divided into two classes one of which contained a few strains which were highly proteolytic ( $>150 \mu \mathrm{g}$ tyrosine $/ \mathrm{ml}$ ) and the other, a larger number of strains capable of releasing not more than $50 \mu \mathrm{g}$ tyrosine/ml. Thermobacteria and enterobacteria showed very variable proteolytic activity, while mesophilic streptococci had low activities. All yeast strains showed fairly good proteolytic activities.

Natural whey cultures can release $66-72 \mu \mathrm{g}$ tyrosine/ml under the same experimental conditions.

\section{Discussion and conclusions}

The major aim of this study was to quantify the main microbial groups and to isolate the largest possible number of different species occurring in natural whey starters. The microbial contents were characterized by large variability; this is attributable in part to the difficulties in the enumeration of the different groups of microorganisms. No selective media are available for many of those groups and those that are are of little value (e.g. Mayeux and WL agars for Leuconostoc and Pediococci respectively). Nevertheless the results show an obvious and complete predominance of lactic acid bacteria. Many species of the genera Lactobacillus and Streptococcus were isolated. The presence of both thermophilic and mesophilic species can be attributed to the incubation conditions and use of natural whey starters in the manufacture of Mozzarella cheese.

Lower counts of other microbial groups (enterococci, Leuconostocs, enterobacteria, yeasts) were obtained. Nonetheless they may be responsible for some biochemical activity in the manufacture of Mozzarella cheese from waterbuffalo milk.

The numerical importance of the enterococci suggests that further research on their role in proteolysis during curd ripening should be carried out.

Leuconostocs, enterobacteria and yeasts reached counts in the range of $10^{4} / \mathrm{ml}$ in some instances but more often $>10^{5}$. Their biochemical activities should also be taken into account. The ability of Leuconostoc to produce flavour compounds and to synthetize large amounts of extracellular polysaccharides could be important in Mozzarella cheese manufacture.

The occurrence of enterobacteria (about $10^{6} \mathrm{cfu} / \mathrm{ml}$ ) is related to the use of raw milk and to the storage conditions of the whey culture, neither of which include any kind of precaution or control of contamination. Current manufacturing technologies of Mozzarella cheese relies, as in the past (SCASSELATI-SFORZOLINI et al., 1956), on the heat treatment of the curd during stretching for the destruction of pathogenic or potentially pathogenic microorganisms. However, coliforms are often found in the product ready for consumption, because the curd stretching step includes an uneven temperature profile and because subsequent contamination occurs. The claim by HowIE (1981), that E. coli, whatever its number, is not an indicator of the occurrence of enteric pathogens like Salmonella and Shigella in dairy products is widely 
acceptable. The contribution of these microorganisms to the transformation of water-buffalo milk into Mozzarella cheese cannot be considered secondary, both because of their active metabolism (proteolysis, mixed sugar fermentation, etc.) and because of the size their population attains during curd ripening. However, the isolation of enteropathogenic serotypes infers that about $50 \%$ of the strains of $E$. coli isolated could be agents of infant or adult diarrhoea. Therefore, the occurrence of these microorganisms represents a health risk and it is concluded that the rationalization of Mozzarella cheese manufacture must involve the pasteurization of cheese milk and the use of technologies that inhibit the growth and production of toxins by E. coli.

Finally, yeasts can reach high numbers in the whey culture. Previous studies (ADDEO and COPPOLA, 1983) showed that they do not multiply during curd ripening. The role they play in this biological system, in synergy with other microbial groups, is not understood. Further investigations may show a role for them; at present there is no experimental evidence to suggest that these micoorganisms must be considered contaminants.

In conclusion the natural whey cultures currently used as starters in Mozzarella cheese manufacture consist of a large number of microorganisms and a great variety of microbial groups. The occurrence of potentially pathogenic microorganisms and the inconstant technological performances of the starter suggest that natural whey cultures should be replaced by selected starters of known composition. It is felt, though, that the range of biochemical activities attributable to the complex microflora of the natural starters described in this study cannot be reproduced using simple associations of lactobacilli and streptococci.

Reçu le 19 août 1986. Accepté pour publication le 15 janvier 1988.

\section{Acknowledgements}

This research was supported by grants provided by Regione Campania and Ministero della Pubblica Istruzione, Rome.

\section{References}

Accolas J.P., Auclair G., 1964. Etude bactériologique des levains utilisés dans la fabrication de Gruyère. Ann. Technol. Agric. INRA, 13, 85-96.

Addeo F., Coppola S., 1983. Aspetti tecnologici e microbiologici della trasformazione del latte di bufala in mozzarella. Latte, $8(10)$, 706-723.

ANNIBALDI S., 1969. Modificazione della prova di Weinzirl per la ricerca dei clostridi butirrici nel latte. Sci. Tec. Latt.-Casearia, 20 (4), 75-79.

Barnes E.M., 1956. Methods for the isolation of faecal streptococci (Lancefield Group D) from bacon factories. J. Appl. Bacteriol., 19 (2), 193-203.

Barnett J.A., Payne R.W., Yarrow D., 1983. Yeasts. Characteristics and identification. Cambridge University Press, Cambridge, London and New York.

Bottazzı V., 1962. Ricerche sulla microbiologia del formaggio Grana. Nota III. Studio della microflora del siero-fermento usato nella fabbricazione del formaggio Grana tipico. Ann. Microbiol., 12 (1), 59-72.

Bottazzi V., Bersani C., Sarra P.G., Magri M., 1977. Caratteristiche dei batteri lattici presenti nelle colture naturali in siero. 1. Tassonomia, morfologia, attività da beta-galattosidasi e da lattico-deidrogenasi. Sci. Tec. Latt.-Casearia, 28 (6), 430-442. 
Bottazzi V., Vescovo M., 1973. Ricerche sulla microbiologia del formaggio Grana. IX parte: Caratteri e distribuzione dei biotipi di $L$. helveticus nelle colture naturali (sieri-fermenti). Sci. Tec. Latt.-Casearia, 24 (1), 23-39.

Bourgeois C.M., Leveau J.Y. (eds.), 1980. Techniques d'analyse et de contrôle dans les industries agro-alimentaires. Volume 3. Le contrôle microbiologique. APRIA, Paris, 122.

Chapman H.R., Sharpe M.E., 1981. Microbiology of cheese. In : Dairy microbiology. vol. 2, ed. Robinson R.K., Applied Sciences Publishers, London and New York, 157-243.

Citti J.E., Sandine W.E., Elliker P.R., 1963. Some observations on the Hull method for measurement of proteolysis in milk. J. Dairy Sci., 46, 337.

Coppola S., Parente E., Dumontet S., Coppola R., 1985. La fabbricazione della mozzarella di bufala : attività fermentative durante la maturazione della cagliata. Ann. Microbiol., 35, 211220.

Davis J.G., 1958. A convenient semisynthetic medium for yeast and mould counts. Lab. Pract., 7 , 30.

Deibel R.H., Seeley H.W., 1974. Streptococcaceae fam. nov. In : Bergey's Manual of Determinative Bacteriology, ed. Buchanan R.E. and Gibson N.E., Gibbons R.E., Baltimore N.E., Williams and Wilkins.

Elliker P.R., Anderson A.W., Hannesson G., 1956. An agar culture medium for lactic streptococci and lactobacilli. J. Dairy Sci., 39, 1611-1612.

Formisano M., Mincione B., 1982. Studio monografico sugli aspetti bio-tecnologici della lavorazione del latte di bufala. Arti Grafiche Russo, Caserta.

Galli A., Ottogalli G., Volonterio G., 1984. Metodo per la conta ed identificazione dei batteri propionici nei prodotti lattiero-caseari. Ind. Latte, 20 (1), 19-32.

Garvie E.I., 1967. Leuconostoc oenos sp. nov. J. Gen. Microbiol., 48 (3), 431-438.

Harrigan W.F., McCANCE M.E., 1976. Laboratory methods in food and dairy microbiology. Academic Press, London, 320-321.

HowiE J., 1981. Significance of Escherichia coli in cheese. Lancet, October 24, 939.

Hul. M.E., 1947. Studies on milk proteins. II. Colorimetric determination of the partial hydrolysis of the proteins of milk. J. Dairy Sci., 30, 881 .

Krush von U., LOMPE A., 1982. Schnellest zum qualitativen Nachweis von $L(+)$ - und D(-)-Milchsaure fur die Bestimmung von Milchsaurebakterien. Milchwissenschaft, 37 (2), 6568.

Law B.A., 1982. Cheeses. In : Fermented foods, ed. Rose A.H., Academic Press, London, 148198.

LoDder J., 1970. The yeasts, North-Holland Publ. Co., Amsterdam.

de Man J.C., Rogosa M., Sharpe M.E., 1960. A medium for the cultivation of lactobacilli. J. Appl. Bacteriol., 23 (2), 130-135.

Matreuzzi D., 1967. Studi sulla microflora dei sieri-innesti del formaggio Parmigiano-Reggiano. Nota I. Identificazione delle specie più rappresentative. Ann. Microbiol., 17 (2), 201-210.

Mayeux J.V., Sandine W.E., Elliker P.R., 1962. A selected medium for detecting leuconostoc organisms in mixed strains starter cultures. J. Dairy Sci., 45, 655-656.

Ministero della sanita' della Repubblica italiana, 1978. Circolare $\mathbf{n}^{\circ} 88$. December 15.

NAyLor J., Sharpe M.E., 1957. Lactobacilli in Cheddar cheese I. The use of selective media for isolation and of serological typing for identification. J. Dairy Res., 25, 92-103.

Rogosa M., 1974. Genus I. Lactobacillus. In : Bergey's Manual of Determinative Bacteriology, ed. Buchanan R.E. and Gibson N.E., Gibbons R.E., Baltimore N.E., Williams and Wilkins.

Scasselati-Sforzolini G., Rossini G., Mariotti G., 1956. Influenza della tecnica di lavorazione della mozzarella sul contenuto microbico del prodotto finito. Nuovi Ann. Ig. Microbiol., 7 (2), 133-138.

Valles E., MocQuot G., 1972. Etude sur la technique de préparation de la présure utilisée dans les fabrications traditionnelles des fromages de gruyère de Comté et d'Emmental. Lait, 52 (515-516), 259-282.

Vedamuthu E.R., Washam C., 1983. Cheese. In : Biotechnology vol. 5, ed. Rehm H.J., Reed G., Verlag-Chemie, Weinheim, 213-313. 